\title{
ANALISIS FAKTOR-FAKTOR SUSTAINABILITAS BAITUL MAAL WAT \\ TAMWIL (BMT)
}

\author{
Muhammad Aswad \\ Institut Agama Islam Negeri Tulungagung \\ maswad75000@gmail.com
}

\begin{abstract}
Baitul Mal wa at-Tamwil (BMT) is a Syari'ah financial institution that continues to grow and keeps its sustainability among the competition of financial services institutions. Eventhough BMT grows rapidly, it experiences many obstacles in its development, but it still exists independently. This study examines the factors that affect the sustainability of BMT in Indonesia, the Factor Analysis and Regression Analysis methods were used in data analysis. The finding of this study reveals that management, human resources, capital, and product innovation factors affected BMT performance. Through regression analysis it is found that management factors and human resources factors have a significant effect on the sustainability of $B M T$.
\end{abstract}

Keywords: Management, Capital, Product Innovation, Sustainability, BMT

\begin{abstract}
Abstrak
Baitul Mal wa at-Tamwil (BMT) adalah lembaga keuangan syariah yang terus tumbuh dan sustainabel di tengah persaingan lembaga jasa keuangan. Meski berkembang pesat BMT mengalami banyak kendala dalam perkembangannya, namun tetap mampu eksis dengan kemandiriannya. Penelitian ini mengurai faktor-faktor yang mempengaruhi sustainabilitas BMT di Indonesia, dengan menggunakan metode Analisis Faktor dan Analisis Regresi. Hasil penelitian ini menemukan bahwa faktor Manajemen, faktor SDM, faktor Permodalan, dan faktor Inovasi Produk berpengaruh kinerja BMT. Dengan analisis regresi menemukan bahwa faktor Manajemen dan faktor SDM berpengaruh signifikan terhadap sustainabiltas BMT.
\end{abstract}

Kata Kunci: Manajemen, SDM, Permodalan, Inovasi Produk, Sustainabilitas, BMT 


\section{A. PENDAHULUAN}

Kemunculan industri keuangan mikro syariah dipelopori berdirinya Baitul Mal wa at-Tamwil (BMT) Ridho Gusti yang didirikan di Bandung pada tahun 1990. Perlahan tapi pasti pertumbuhan BMT mulai meningkat sampai tahun 1995 dan menuju puncaknya di saat krisis di tahun 1996-1998. BMT di Indonesia membuktikan kemampuannya dalam menghadapi krisis global, di saat lembaga keuangan lainnya collapse dan terpaksa mendapatkan bantuan pemerintah untuk tetap bertahan, BMT mampu bertahan, bahkan jumlahnya di Indonesia semakin berkembang pesat.

Salah satu penyebab bertahannya institusi ini adalah faktor kemandirian (independency) dan investasi sektor riil yang dimilikinya. Seperti diungkapkan Qayyum dan Munir memberikan contoh lembaga keuangan mikro Grameen Bank di Bangladesh dan BancoSol di Bolivia adalah lembaga keuangan mikro yang sustainabel karena ditopang kemandirian lembaga dari manajemen pengelolaan keuangan memadai dan pelayanan pada nasabah masyarakat kecil, sehingga membuat mampu maju seperti perbankan umumnya. ${ }^{1}$

Di Indonesia sustainabel BMT dapat dilihat dengan kinerja BMT secara nasional telah mencapai aset sebesar $\operatorname{Rp} 4,7$ triliun dan jumlah pembiayaan sebesar Rp 3,6 triliun. Sementara jumlah lembaga BMT dari tahun ke tahun semakin meningkat. Hingga saat ini diperkirakan jumlah BMT di Indonesia sebanyak 4500 unit. $^{2}$

1 Abdul Qayyum dan Munir Ahmad, "Efficiency and Sustainability of Micro Finance Institutions in South Asia," Research Journal Social Sciences 3, no. 1 (2006): 2.

${ }^{2}$ Yusuf Wibisono dan Tika Arundina, Indonesia shari'ah economic outlook (ISEO), 2011, ed. oleh Yusuf Wibisono (Jakarta: Lembaga Penerbit, Fakultas Ekonomi, Universitas Indonesia, 2011), 77-79. 


\section{Gambar 1. Pertumbuhan BMT 1990-2018}

चumlah BMT - Periode

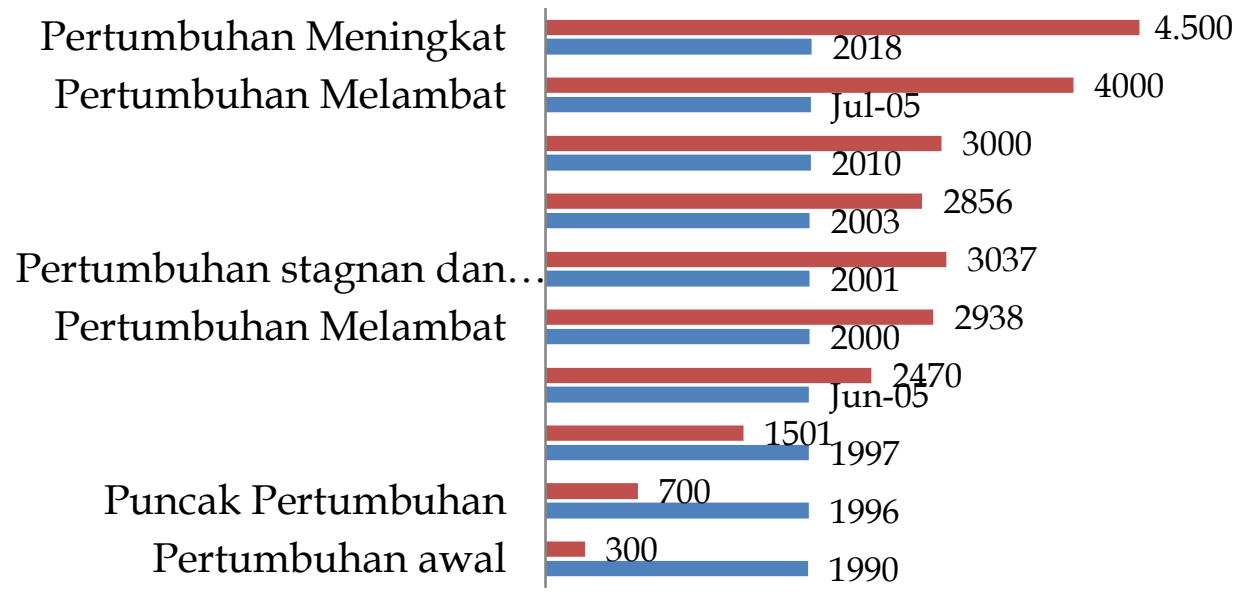

Tingginya perkembangan lembaga BMT dalam tiga dasawarsa, tentu karena BMT mampu survive dan kompetitif di tengah persaingan antar lembaga keuangan khususnya lembaga keuangan mikro syariah. Oleh karena itulah, BMT harus mampu mendapatkan profit karena menjadi sinyal keberlanjutan BMT dan perkembangannya di masa depan dan sinyal tentang alokasi sumberdaya yang efisien. Profit bukan sekedar sebagai syarat BMT dapat melangsungkan keberlanjutan program pembiayaan, namun sebagai syarat perkembangan BMT di masa yang akan datang. Dengan profit BMT dapat terus melayani masyarakat yang kemudian memberikan manfaat sosial. Tanpa profit langkah-langkah pengembangan tidak mungkin dilaksanakan, maka profit menjadi sumber pengembangan BMT yang berkelanjutan. ${ }^{3}$

BMT yang mampu berkembang (grow) dan maju berkelanjutan (sustainable) dapat dilihat pada kinerja BMT yang meliputi keterjangkauan (outreach) dan keberlanjutan (sustainability). Dari sisi keterjangkauan yang dijadikan tolok ukur adalah kualitas layanan yang diberikan BMT terhadap nasabah (anggota) dan jumlah kantor cabangnya. Sedangkan keberlanjutan

${ }^{3}$ Widiyanto bin Mislan Cokrohadisumarto, Abdul Ghafar Ismail, dan Kartiko A. Wibowo, ed., BMT, Praktik dan Kasus, Cetakan ke-1 (Jakarta: RajaGrafindo Persada, 2016), 31. 
(sustainability) di mana BMT memiliki daya tahan dan kemandirian dalam menarik konsumen pendanaan dan pembiayaan tanpa didukung pendanaan dana asing ataupun subsidi bantuan dana pemerintah.

Association for Social Advancement (ASA) Sustainabilitas dilihat dalam dua bentuk yaitu sustainabilitas lembaga dan sustainabilitas keuangan. Sustainabilitas lembaga merupakan kemampuan LKM dalam pengelolaan secara berkelanjutan dengan adanya faktor keberhasilan dalam mewujudkan cost-effectiveness dalam tatakelola LKM. Sementara sustainabilitas keuangan di mana LKM memiliki kemampuan dalam manajemen keuangan LKM dan mampu mencukupi biaya operasional atau biaya-biaya untuk jangka panjang. Sustainabilitas LKM dilihat dari kesinambungan operasionalnya dengan kemampuan menutupi biaya operasional secara mandiri. Juga LKM memenuhi biaya operasional, biaya dana, biaya inflasi dan semua biaya-biaya kas tanpa subsidi dana. ${ }^{4}$

Selain beberapa faktor di atas, sustainabilitas BMT hingga sekarang, dan telah mampu berperan signifikan terhadap perekonomian masyarakat Indonesia tidak terlepas dari peranan sumberdaya manusia atau biasa dikenal dalam ekonomi syariah sumberdaya insani (SDI). Seperti diungkapkan Salam bahwasanya sustainabilitas koperasi maupun koperasi syariah (BMT) sangat ditentukan faktor SDM, jangkauan pasar meliputi account officer dan jumlah debitur, inovasi produk, dan manajemen operasional. Keempat faktor ini secara simultan sebagai penggerak keberlangsungan BMT di tengah persaingan lembaga keuangan kompetitif. ${ }^{5}$

Dalam keberlangsungan BMT terlihat dengan kemampuan BMT sebagai suatu lembaga keuangan mikro syariah dalam mendapatkan keuntungan yang berkelanjutan (long term profit) dari nasabah atau anggota (customer)

${ }^{4}$ Ayi Cavriel Ayayi dan Maty Sene, "What Drives Microfinance Institutions Sustainability," vol. 44, 1 (Journal of Developing Areas, 2010), 306.

5 Abdul Salam, Sustainabilitas Lembaga Keuangan Mikro: Koperasi Simpan Pinjam, ed. oleh Hasse J (Yogyakarta: Sekolah Pascasarjana UGM, 2008), 26. 
apabila para karyawan (SDM) memaksimalkan pelayanan (total quality service) kepada anggota/nasabah akan melahirkan on going relationship di antara nasabah dengan pengelola BMT. Tentu dengan kualitas pelayanan maksimal oleh sumber daya manusia (SDM) yang berkualitas dalam kinerjanya sekaligus memiliki rasa memiliki (sense of ownership) terhadap BMT. Oleh karenanya, sumber daya manusia sangat vital didalam keberhasilan BMT.

Namunpun demikian, BMT tetap saja menghadapi kendala dan tantangan untuk mampu eksis kompetitif dengan lembaga jasa keuangan lainnya. BMT sebagai lembaga penyedia jasa keuangan syariah bagi masyarakat usaha kecil mikro (UMK). Eksposur UMK umumnya tidak memiliki agunan, tidak berbadan hukum, mobilitas tinggi menjadikan usaha UMK adalah berisiko tinggi, ditambah lagi regulasi tentang jaminan dana belum terakomodir. Juga menjadi permasalahan mendasar bagi pengelola BMT tidak memadainya sumberdaya manusia terdidik, terampil profesional dalam pengembangan budaya dan jiwa kewirausahaan. Termasuk permodalan relatif kecil dan terbatas, BMT juga mengalami tingkat kepercayaan rendah, adanya sikap ambivalensi dalam sharia compliance antara konsep dengan operasionalisasi BMT di lapangan. Dengan kompleksitas BMT seperti ini berefek pada persepsi publik terhadap BMT dibanding lembaga keuangan konvensional. ${ }^{6}$

Meskipun demikian besar tantangannya, BMT memiliki konstribusi besar bagi pembangunan ekonomi bangsa Indonesia dengan nilai syariah terutama sebagai solusi (panacea) bagi terberdayanya usaha kecil mikro dan menengah, bahkan menjadi pilar perekonomian kerakyatan dan sistem ekonomi nasional. Hal ini telah menjadi gambaran bahwa BMT mampu berperan bagi masyarakat karena mampu memberi solusi konsktruktif bagi UMK khusunya pemberian modal usaha. BMT tidak hanya menyalurkan

${ }^{6}$ Wibisono dan Arundina, Indonesia shari'ah economic outlook (ISEO), 2011, 66. 
pembiayaan secara komersil namun juga memiliki fungsi sosial masyarakat.

Berdasarkan latar belakang masalah tersebut, sustainabiltas BMT tentu dipengaruhi beberapa variabel di antaranya: (1) Apa saja faktor-faktor yang mempengaruhi sustainabilitas BMT? (2) Apakah faktor SDM, Manajemen, Permodalan, Inovasi Produk, Ekonomi Makro dan Regulasi berpengaruh signifikan terhadap Sustainabilitas BMT? (3) Bagimana faktor SDM, Manajemen, Permodalan, Inovasi Produk, Ekonomi Makro dan Regulasi berpengaruh terhadap Sustainabilitas BMT?

\section{B. HASIL PENGOLAHAN DATA}

\section{Metode Penelitian}

Setelah data terkumpul melalui penyebaran kuisioner dalam bentuk google forms yang didapatkan dengan tekhnik sampel purposif di beberapa BMT di dua kabupaten Jawa Timur dan 2 kabupaten/kota di Sulawesi Selatan. Tekhnik sampel purposif diambil berdasarkan pada pertimbangan populasi data yang menyebar di mana peneliti tidak mempunyai informasi awal tentang populasi. ${ }^{7}$ Dalam hal ini sampelnya adalah para manajer/pengelola BMT. Berdasarkan data kuisioner diolah dan dianalisis dengan metode Analisis Faktor. Penggunaan analisis faktor untuk mereduksi data, yaitu proses untuk meringkas sejumlah variabel menjadi lebih sedikit dan menamakannya sebagai faktor. Dengan demikian dapat saja dari enam atribut yang mempengaruhi sustainabilitas BMT, setelah dilakukan analisis faktor menjadi empat faktor. Variabel-variabel yang dilakukan analisis faktor adalah: (1) Sustainabilitas BMT (2) SDM (3) Manajemen (4) Inovasi Produk (5) Makro Ekonomi (6) Regulasi. Berdasarkan Anti-image Correlation terlihat angka-angka yang membentuk diagonal dan mempunyai notasi “a”. Di mana angka-angka ini merupakan besaran Measures of Sampling Adequacy(MSA) dari

\footnotetext{
${ }^{7}$ Hendri Tanjung dan Abrista Devi, Metodologi Penelitian Ekonomi Islam. (Jakarta: Gramata Publishing, 2013), 117.
} 
semua variabel mempunyai nilai MSA di atas $0,50 .{ }^{8}$ Menjelaskan apabila semua variabel telah memiliki nilai MSA di atas 0,50, analisis lebih lanjut dapat dilakukan dengan Analisis Regresi. Analisis regresi sebagai tekhnik asosiatif, yaitu bertujuan mempelajari pengaruh variabel bebas terhadap variabel tidak bebas. Dalam analisis regresi mengukur koofisien korelasi antara $\mathrm{X}$ dan $\mathrm{Y}$, uji hipotesis dan mengukur koofosien determinasi. ${ }^{9}$

\section{Kerangka Konseptual}

Terdapat beberapa faktor yang membuat lembaga keuangan BMT mampu eksis dan kompetitif hingga sustainabel dan mapan di antaranya: pertama, faktor regulasi dan supervisi. Seperti dalam Staschen, ${ }^{10}$ bahwa dengan hadirnya regulasi dan supervisi telah berpengaruh atas berkembang dan keberlangsungan BMT. Dengan regulasi sebagai panduan dalam mengatur lembaga, bagaimana BMT beroperasi sesuai dengan regulasi yang ditetapkan. Sementara supervisi mengawal dan memastikan BMT mampu melaksanakan aturan-turan sesuai dengan regulasi yang ditetapkan. Regulasi dapat dipahami juga pengaturan yang berkaitan lembaga keuangan mikro bisa berbentuk undang-undang ataupun peraturan pemerintah. Urgensi regulasi terhadap eksistensi lembaga keuangan karena hadirya BMT menjadi kebutuhan masyarakat bagi pelaku UMKM. BMT sebagai lembaga keuangan syariah dengan sistem bagi hasil dan resiko dalam operasionalnya. Seperti diungkapkan Chideme bahwa LKM tidak akan mampu sebagai lembaga intermediasi dari unit surplus dengan unit depisit yang efektif tanpa adanya regulasi dalam suatu negara tersebut. ${ }^{11}$

\footnotetext{
8 Imam Gunawan, Pengantar Statistika Infrensial, 1 ed. (Jakarta: Raja Grafindo Persada, 2016), 284-93.

9 Abdul Kadir, Statistika Terapan: Konsep, contoh dan Analisis Data dengan Program SPSS/Lisrel dalam Penelitian, 3 ed. (Jakarta: Raja Grafindo Persada, 2018), 177-89.

10 Stefan Staschen, "Regulation and Supervision of Microfinance Institutions: State of Knowledge" (Deutsche Gesellschaft für Technische Zusammenarbeit (GTZ) GmbH, 1999), 1.

${ }^{11}$ Nyikadzino Chideme, "An Assessment of Factors Affecting the Financial Performance of Microfinance Institutions in Zimbabwe" (A dissertation submitted in partial fulfillment of the requirements for the degree of Master of Business Administration 2015, Zimbabwe, Graduate School of Management University of Zimbabwe, 2015), 38.
} 
Kedua, faktor permodalan dalam eksistensi dan kapasitas lembaga. Kelembagaan BMT mampu eksisten karena ditopan kapasitas lembaga. Berkaitan kapasitas lembaga dapat diukur adalah aspek permodalan BMT dan jumlah jaringan kantor cabang. Meningkatnya kapasitas lembaga karena terjadinya peningkatan permodalan yang disumbang dari modal internal yang bersumber dari setoran dana (funding) para anggota koperasi. ${ }^{12}$

Ketiga, Faktor sumber daya manusia adalah hal paling vital mendukung eksisnya BMT. Sumber daya manusia dapat didefiniskan sebagai alat untuk mencapai tujuan. Sumber daya manusia merupakan orang-orang yang merancang dan menghasilkan barang dan jasa, mengawasi mutu, memasarkan produk, mengalokasikan sumber daya finansial serta merumuskan strategi dan tujuan organisasi. ${ }^{13}$ Persoalan SDM adalah hal yang mendasar dalam eksistensi BMT. SDM yang kompeten pada BMT adalah SDM yang terampil, berpengetahuan khususnya manajemen keuangan syariah, sikap (attiudes), nilai-nilai (values), kebutuhan-kebutuhan (nedds). Segala unsur yang kompeten pada akshirnya akan mempengaruhi peranan dan perilaku SDM terhadap organisasi. ${ }^{14}$ Dalam hal ini organisasi lembaga keuangan mikro syariah yaitu BMT.

Keempat, Manajemen adalah proses menggerakkan tenaga manusia, modal dan peralatan lainnya secara terpadu untuk mencapai tujuan tertentu, kombinasi antara kebijakan, administrasi dan oarang yang mengambil keputusan dan pengawasan yang dibutuhkan untuk mencapai stabilitas dan pertumbuhan usaha. ${ }^{15}$ Manajemen BMT adalah lembaga keuangan syariah yang mesti dikelola secara profesional. Dalam pengelolaan BMT maka aspek

12 Oded Galor, "The Demographic Transition and the Emergence of Sustained Economic Growth," Journal of the European Economic Association 3, no. 2-3 (1 Mei 2005): 394, https://doi.org/10.1162/jeea.2005.3.2-3.494.

${ }^{13}$ Sadili Samsudin, Managemen Sumber Daya Manusia (Bandung: Pustaka Setia, 2006), 21.

${ }^{14}$ Faustino Cardoso Gomes, Manejemen Sumber Daya Manusia (Yogyakarta: Andi, 2003), 26, http://ucs.sulsellib.net//index.php?p=show_detail\&id=17721.

15 Sri Redjeki Hartono, Paramita Prananingtyas, dan Fahimah, Kamus hukum ekonomi (Bogor: Ghalia Indonesia, 2010), 110-11. 
yang berkaitan tata kelola ekonomi dan manajemen keuangan harus dikuasai secara maksimal. Disamping itu juga manajemen BMT harus bisa menyesuaikan terhadap perkembangan tekhnologi yang digunakan dalam pengelolaan BMT sehingga tidak ketinggalan zaman yang berdampak pada lemahnya kompetisi BMT dalam menambah minat nasabahnya. Kajian kognisi manajemen meliputi di empat hal: planning (perencanaan), actuating (pelaksanaan), organizing (pengorganisasian) dan controlling (pengontrolan). ${ }^{16}$

Kelima, inovasi dapat diartikan sebagai kegiatan pengembangan atau perekayasaan yang bertujuan mengembangkan penerapan praktis nilai dalam konteks inovasi produk disesuaikan pada nilai keuangan Islam pada produk jasa keuangan mikro. Inovasi produk BMT harus ditingkat di mana mampu merebut pasar keuangan mikro. Agar BMT bisa bersaing dengan sesama lembaga keuangan yang menawarkan jasa keuangan dengan pesaing kuat seperti lembaga keuangan konvensional yang lebih dulu eksis. Maka sepatutnya BMT bisa menyeimbangkan dengan produk-produk lembaga keuangan konvensional. Produk yang dikembangkan tentunya berdasarkan pada suatu perencanaan dan pelaksanaan berdasarkan kebutuhan pasar. BMT memang harus bisa membaca apa yang dibutuhkan oleh nasabah saat ini, untuk memberikan varian alternatif yang bisa dipilih oleh nasabah berkaitan produk simpanan ataupun produk pembiayaan yang ditawarkan.

Keenam, Faktor kondisi ekonomi makro menjadi salah satu faktor yang mempengaruhi keberlangsungan BMT. Seperti yang dilangsir Asian Development Bank mengungkapkan bahwa kondisi perekonomian menjadi penentu pengembangang LKM, terkhusus dengan stabilitas ekonomi melalui stabilnya harga-harga komoditi, harga produk jasa dan barang, pertumbuhan

16 Aam S Rusydiana dan Abrista Devi, "Aplikasi Metode Analytical Network Process (ANP) untuk Mengurai Problem Pengembangan Baitul Maal Wat-Tamwil di Indonesia," 2013, 5-6, https://www.academia.edu/download/32794292/Aplikasi_Metode_ANP_untuk_Mengurai_Problem_Pe ngembangan_BMT_di_Indonesia.pdf. 
ekonomi dan pembangunan infrastruktur di pedesaan. ${ }^{17}$

\section{PEMBAHASAN}

Metode yang digunakan dalam penelitian ini adalah analisis faktor. Analisis faktor adalah prosedur analisis yang digunakan untuk data reduction dan summarization, atau mereduksi dimensi. Analisis faktor merupakan tekhnik interdependen untuk menguji hubungan sekumpulan variabel. Selanjutnya proses pada analisis faktor meliputi: 1) Merumuskan masalah, 2) Menyusun matriks korelasi; 3) Ekstraksi faktor 4) Merotasi faktor, 5) Interpretasikan faktor; 6) Pembuatan faktor skors dan terakhir 7) Pilih surrogate variabel (variabel pengganti). Analisis selanjutnya menggunakan Analisis Regresi Linear Berganda. Analisis tujuannya untuk mengukur taraf signifikansi dari variable faktor yang telah diuji sebelumnya.

\section{Menyusun Matriks Korelasi}

Langkah selanjutnya menyusun matrik korelasi dengan SPSS 23. Selanjutnya output KMO and Bartlett's Test dapat diketahui sebagai berikut:

Tabel 1. KMO and Bartlett's

\begin{tabular}{|c|c|c|}
\hline \multicolumn{3}{|c|}{ KMO and Bartlett's Testa } \\
\hline \multicolumn{2}{|c|}{$\begin{array}{l}\text { Kaiser-Meyer-Olkin Measure of Sampling } \\
\text { Adequacy. }\end{array}$} & .719 \\
\hline \multirow{3}{*}{$\begin{array}{l}\text { Bartlett's Test of } \\
\text { Sphericity }\end{array}$} & Approx. Chi-Square & 437.246 \\
\hline & $\mathrm{df}$ & 21 \\
\hline & Sig. & .000 \\
\hline
\end{tabular}

Dari data KMO and Bartlett's Test tersebut menunjukkan dengan nilai 437.246>0,5 terdapat signifikansi antar variabel. Kaiser-Meyer-Olkin Measure of Sampling Adequacy sebesar 0.719 > 0,5 menunjukkan terdapat signifikansi antar 17 Asian Development Bank, "Finance for the Poor: Microfinance Development Strategy" (Manila
ADB, 2000), 2 . 
variabel. Langkah selanjutnya dengan mengkaji anti image

Tabel 2. Measures of Sampling Adequacy(MSA)

\begin{tabular}{|l|r|r|r|r|r|r|r|}
\hline & $\begin{array}{c}\text { Sustai } \\
\text { nabilit } \\
\text { as }\end{array}$ & SDM & $\begin{array}{r}\text { Manajeme } \\
\mathrm{n}\end{array}$ & $\begin{array}{c}\text { Permoda } \\
\text { lan }\end{array}$ & $\begin{array}{l}\text { Inovasi } \\
\text { Produk }\end{array}$ & $\begin{array}{c}\text { Makro } \\
\text { Ekonomi }\end{array}$ & $\begin{array}{c}\text { Regula } \\
\text { si }\end{array}$ \\
\hline Sustainabilitas & .561 & -.218 & -.149 & -.048 & -.033 & -.065 & -.106 \\
SDM & -.218 & .575 & -.176 & .043 & -.086 & .088 & .063 \\
Manajemen & -.149 & -.176 & .497 & -.239 & -.052 & -.113 & -.020 \\
Permodalan & -.048 & .043 & -.239 & .762 & -.017 & .095 & .064 \\
Inovasi Produk & -.033 & -.086 & -.052 & -.017 & .909 & -.066 & -.062 \\
Makro Ekonomi & -.065 & .088 & -.113 & .095 & -.066 & .941 & -.006 \\
Regulasi & -.106 & .063 & -.020 & .064 & -.062 & -.006 & .965 \\
\hline Sustainabilitas & $.758 \mathrm{a}$ & -.384 & -.282 & -.073 & -.046 & -.090 & -.143 \\
SDM & -.384 & $.718 \mathrm{a}$ & -.330 & .065 & -.119 & .120 & .085 \\
Manajemen & -.282 & -.330 & $.716 \mathrm{a}$ & -.388 & -.077 & -.166 & -.029 \\
Permodalan & -.073 & .065 & -.388 & $.682 \mathrm{a}$ & -.020 & .112 & .074 \\
Inovasi Produk & -.046 & -.119 & -.077 & -.020 & $.865 \mathrm{a}$ & -.072 & -.066 \\
Makro Ekonomi & -.090 & .120 & -.166 & .112 & -.072 &.$\underline{473}$ & -.007 \\
Regulasi & -.143 & .085 & -.029 & .074 & -.066 & -.007 & $.467 \mathrm{a}$ \\
\hline
\end{tabular}

a. Measures of Sampling Adequacy(MSA)

Anti image correlation matriks menunjukkan terdapat dua variabel dengan taraf signifikansi di bawah 0,5 yaitu makro ekonomi $(0,473)$ dan regulasi $(0,467)$. Oleh karena terdapat dua faktor dengan nilai MSA dibawah 0,5 maka kedua faktor dikeluarkan yaitu faktor makro ekonomi dan faktor regulasi. Dengan menganalisis kembali dari faktor yang tersisa yaitu dengan taraf signifikansi di atas 0,5. yaitu faktor, sustainabilitas, SDM, manajemen, permodalan dan inovasi produk dengan hasil sebagai berikut:

Tabel 3. Anti-image Matrices

\begin{tabular}{|l|l|r|r|r|r|r|}
\hline \multicolumn{2}{|c|}{} & Sustainabilitas & SDM & Manajemen & $\begin{array}{r}\text { Permoda } \\
\text { lan }\end{array}$ & $\begin{array}{r}\text { Inovasi } \\
\text { Produk }\end{array}$ \\
\hline Anti- & Sustainabilitas & .578 & -.216 & -.169 & -.036 & -.046 \\
image & SDM & -.216 & .588 & -.173 & .031 & -.078 \\
nce & Manajemen & -.169 & -.173 & .512 & -.237 & -.063 \\
& Permodalan & -.036 & .031 & -.237 & .776 & -.006
\end{tabular}




\begin{tabular}{|c|c|c|c|c|c|c|}
\hline \multirow{6}{*}{$\begin{array}{l}\text { Anti- } \\
\text { image } \\
\text { Correla } \\
\text { tion }\end{array}$} & $\begin{array}{l}\text { Inovasi } \\
\text { Produk }\end{array}$ & -.046 & -.078 & -.063 & -.006 & .917 \\
\hline & Sustainabilitas & $.766^{\mathrm{a}}$ & -.370 & -.310 & -.054 & -.063 \\
\hline & SDM & -.370 & $.750^{\mathrm{a}}$ & -.315 & .046 & -.107 \\
\hline & Manajemen & -.310 & -.315 & $.724^{a}$ & -.376 & -.093 \\
\hline & Permodalan & -.054 & .046 & -.376 & $.723^{a}$ & -.007 \\
\hline & $\begin{array}{l}\text { Inovasi } \\
\text { Produk }\end{array}$ & -.063 & -.107 & -.093 & -.007 & $.888^{a}$ \\
\hline
\end{tabular}

a. Measures of Sampling Adequacy(MSA)

Dengan hasil anti image matrices ini menunjukkan seluruh faktor diatas 0,5. Maka tahap selanjutnya adalah:

Tabel 4. Communalities

\begin{tabular}{|l|r|r|r|r|}
\hline \multirow{2}{*}{} & \multicolumn{2}{|c|}{ Raw } & \multicolumn{2}{c|}{ Rescaled } \\
\cline { 2 - 5 } & Initial & Extraction & Initial & \multicolumn{1}{c|}{ Extraction } \\
\hline Sustainabilitas BMT & .729 & .538 & 1.000 & .738 \\
SDM & .496 & .310 & 1.000 & .625 \\
Manajemen & .680 & .504 & 1.000 & .742 \\
Permodalan & .331 & .091 & 1.000 & .274 \\
\hline Inovasi Produk & .291 & .038 & 1.000 & .130 \\
Makro Ekonomi & .546 & .521 & 1.000 & .954 \\
Regulasi & .432 & .024 & 1.000 & .055 \\
\hline
\end{tabular}

Extraction Method: Principal Component Analysis.

Tabel ini menunjukkan pada variabel sustainabilitas sebesar 0,73 (73\%) dapat dijelaskan hubungannya dengan variabel lainnya.

Tabel 5. Initial Eigenvalues

\begin{tabular}{|c|c|c|c|c|c|c|c|c|c|}
\hline \multirow[b]{2}{*}{$\begin{array}{l}\text { Com } \\
\text { pone } \\
\text { nt }\end{array}$} & \multicolumn{3}{|c|}{ Initial Eigenvaluesa } & \multicolumn{3}{|c|}{$\begin{array}{l}\text { Extraction Sums of } \\
\text { Squared Loadings }\end{array}$} & \multicolumn{3}{|c|}{$\begin{array}{c}\text { Rotation Sums of Squared } \\
\text { Loadings }\end{array}$} \\
\hline & Total & $\begin{array}{l}\% \text { of } \\
\text { Varia } \\
\text { nce }\end{array}$ & $\begin{array}{c}\text { Cumulati } \\
\text { ve } \%\end{array}$ & Total & $\begin{array}{c}\% \text { of } \\
\text { Varianc } \\
\text { e }\end{array}$ & $\begin{array}{c}\text { Cumulati } \\
\text { ve } \%\end{array}$ & Total & $\begin{array}{c}\% \text { of } \\
\text { Varianc } \\
\text { e }\end{array}$ & $\begin{array}{c}\text { Cumulative } \\
\%\end{array}$ \\
\hline 1 & 1.479 & 42.218 & 42.218 & 1.479 & 42.218 & 42.218 & 1.408 & 40.184 & 40.184 \\
\hline 2 & .546 & 15.572 & 57.790 & .546 & 15.572 & 57.790 & .617 & 17.606 & 57.790 \\
\hline 3 & .442 & 12.616 & 70.406 & & & & & & \\
\hline 4 & .342 & 9.769 & 80.176 & & & & & & \\
\hline 5 & .274 & 7.814 & 87.990 & & & & & & \\
\hline 6 & .238 & 6.788 & 94.778 & & & & & & \\
\hline
\end{tabular}




\begin{tabular}{|l|r|r|r|r|r|r|r|r|r|}
7 & .183 & 5.222 & 100.000 & & & & & \\
\hline 1 & 1.479 & 42.218 & 42.218 & 2.489 & 35.560 & 35.560 & 2.389 & 34.134 & 34.134 \\
2 & .546 & 15.572 & 57.790 & 1.028 & 14.682 & 50.242 & 1.128 & 16.109 & 50.242 \\
3 & .442 & 12.616 & 70.406 & & & & & & \\
4 & .342 & 9.769 & 80.176 & & & & & & \\
5 & .274 & 7.814 & 87.990 & & & & & & \\
6 & .238 & 6.788 & 94.778 & & & & & & \\
7 & .183 & 5.222 & 100.000 & & & & & & \\
\hline
\end{tabular}

Berdasarkan data Initial Eigenvalues menunjukkan bahwa hanya 1 diatas angka yang terbentuk. Hal ini berarti bahwa hanya membentuk satu faktor

2. Merotasi Matriks

Penjelasan rotasi matriks dapa dijelaskan table di bawah ini:

Tabel 6. Rotasi Matriks

\begin{tabular}{|l|r|r|r|r|}
\hline \multirow{2}{*}{} & \multicolumn{2}{|c|}{ Raw } & \multicolumn{2}{c|}{ Rescaled } \\
\cline { 2 - 5 } & \multicolumn{2}{|c|}{ Component } & \multicolumn{2}{c|}{ Component } \\
\cline { 2 - 5 } & \multicolumn{1}{c|}{1} & \multicolumn{1}{c|}{. } & 1 & \multicolumn{1}{c|}{} \\
\hline Sustainabilitas & .710 & .183 & .832 & .214 \\
SDM & .557 & .008 & .790 & .011 \\
Manajemen & .686 & .183 & .832 & .222 \\
Permodalan & .300 & -.027 & .522 & -.047 \\
Inovasi Produk & .170 & .093 & .316 & .173 \\
Makro & -.037 & .721 & -.050 & .975 \\
Ekonomi & .050 & .145 & .077 & .221 \\
Regulasi & \multicolumn{3}{|l}{}
\end{tabular}

\section{Interpretasikan faktor;}

Tabel 7. Component Matrix ${ }^{a}$

\begin{tabular}{|l|r|}
\hline \multirow{2}{*}{} & \multicolumn{1}{|c|}{ Component } \\
\cline { 2 - 2 } & \multicolumn{1}{|c|}{1} \\
\hline Manajemen & .845 \\
Sustainabilitas & .800 \\
SDM & .783 \\
Permodalan & .584 \\
Inovasi Produk & .437 \\
\hline
\end{tabular}


Component matriks menunjukkan bahwa jumlah yang muncul serta korelasi dengan item dan faktor. Dapat diketahui bahwa hanya 1 faktor dengan loading besar manajemen, sustainabilitas dan SDM. Di mana dengan semakin skor faktor menunjukkan semakin tinggi pengelolaan manajemen dan kualitas SDM nya semakin tinggi pula sustaibilitas BMT .

\section{Pembuatan Faktor Skors}

Selanjutnya faktor skor yang dibuat jika akan dilakukan analisis lanjutan, yaitu analisis regresi. Dalam hal ini memilih surrogate variabel yang paling dapat mewakili satu faktor. Berdasarkan hasil etraksi faktor ditemukan faktor SDM, Manajemen, permodalan dan inovasi produk sebagai variabel independen terhadap sustainabilitas BMT sebagai variabel bebasnya.

Langkah-langkah selanjtnya guna menjawab permasalahan dan tingkat signifikansi penelitian ini dengan metode analisis regresi berganda sebagai berikut:

\section{Uji Validitas dan Realibilitas}

Tabel 8. Uji Validitas dan Realibilitas

\begin{tabular}{|c|c|c|c|}
\hline No & Uji Instrumen Angket & Nilai & Kesimpulan \\
\hline 1 & Uji Validitas & & \\
\hline & $\begin{array}{l}\text { Variabel Dependen } \\
\text { Sustainabilitas BMT }\end{array}$ & $\begin{array}{ll}0, & 841 \geq \\
0,25 & \end{array}$ & Valid \\
\hline & Variabel Independen $\left(\mathrm{X}_{1}\right) \mathrm{SDM}$ & $\begin{array}{ll}0, & 640 \geq \\
0,25 & \end{array}$ & Valid \\
\hline & $\begin{array}{lll}\text { Variabel } & \text { Independen } & \left(\mathrm{X}_{2}\right) \\
\text { Manajemen } & & \end{array}$ & $\begin{array}{ll}0, & 614 \geq \\
0,25 & \end{array}$ & Valid \\
\hline & $\begin{array}{lll}\text { Variabel } & \text { Independen } & \left(\mathrm{X}_{3}\right) \\
\text { Permodalan } & & \end{array}$ & $\begin{array}{ll}0, & 646 \geq \\
0,25 & \end{array}$ & Valid \\
\hline & $\begin{array}{l}\text { Variabel Independen }\left(\mathrm{X}_{4}\right) \text { Inovasi } \\
\text { Produk }\end{array}$ & $\begin{array}{ll}0, & 722 \geq \\
0,25 & \end{array}$ & Valid \\
\hline 2 & Uji Reliabilitas & & \\
\hline
\end{tabular}




\begin{tabular}{|c|c|c|}
\hline $\begin{array}{l}\text { Variabel } \quad \text { Dependen } \\
\text { Sustainabilitas } \\
\text { BMT }\end{array}$ & $\begin{array}{l}0,816 \geq \\
0,25\end{array}$ & Reliabilitas tinggi \\
\hline Variabel Independen $\left(\mathrm{X}_{1}\right) \mathrm{SDM}$ & $\begin{array}{ll}0, & 788 \geq \\
0,25 & \end{array}$ & Reliabilitas tinggi \\
\hline $\begin{array}{lll}\text { Variabel } & \text { Independen } & \left(\mathrm{X}_{2}\right) \\
\text { Manajemen } & & \end{array}$ & $\begin{array}{ll}0, & 783 \geq \\
0,25 & \end{array}$ & Reliabilitas tinggi \\
\hline $\begin{array}{lll}\text { Variabel } & \text { Independen } & \left(\mathrm{X}_{3}\right) \\
\text { Permodalan } & & \\
\end{array}$ & $\begin{array}{ll}0, & 670 \geq \\
0,25 & \end{array}$ & Reliabilitas tinggi \\
\hline $\begin{array}{l}\text { Variabel Independen }\left(\mathrm{X}_{4}\right) \text { Inovasi } \\
\text { Produk }\end{array}$ & $\begin{array}{ll}0, & 772 \geq \\
0,25 & \end{array}$ & Reliabilitas tinggi \\
\hline
\end{tabular}

Seluruh variabel independen dan dependen dapat dinyatakan instrumennya valid dan reliabel dan untuk selanjutnya dapat dianalisis uji asumsi klasik.

\section{Uji Asumsi Klasik}

Tabel 9. Uji Asumsi Klasik

\begin{tabular}{|l|l|l|}
\hline Uji Asumsi Klasik & Nilai dan Taraf Signifikan & Kesimpulan \\
\hline Uji Normalitas & $\begin{array}{l}\text { Kolmogorov-Smirnov Sig. 0,09 } \\
\geq 0,05\end{array}$ & Data distribusi normal \\
\hline Uji Multikoneritas & $\begin{array}{l}\text { Uji VIF } \mathrm{X}_{1}=1.467 \mathrm{X}_{2}=1.766 \\
\mathrm{X}_{3}=1.285 \mathrm{X}_{4}=1.086 \text { semua nilai } \\
\text { VIF }<10\end{array}$ & $\begin{array}{l}\text { Asumsi model tidak } \\
\text { mengandung } \\
\text { multikolinearitas }\end{array}$ \\
\hline Uji Heteroskedastisitas & $\begin{array}{l}\text { Uji Glejser } \mathrm{X}_{1}=0,046 \mathrm{X}_{2}=0,004 \\
\mathrm{X}_{3}=0,043 \mathrm{X}_{4}=0,047 \geq 0,05\end{array}$ & $\begin{array}{l}\text { Tidak terdapat } \\
\text { heteroskedasitas }\end{array}$ \\
\hline
\end{tabular}

\section{Uji Analisis Regresi}

Tabel 10. Analisis Regresi

\begin{tabular}{|c|c|c|c|c|c|c|}
\hline \multicolumn{7}{|c|}{ Coefficients $^{a}$} \\
\hline \multirow{2}{*}{\multicolumn{2}{|c|}{ Model }} & \multicolumn{2}{|c|}{$\begin{array}{c}\text { Unstandardized } \\
\text { Coefficients }\end{array}$} & $\begin{array}{c}\text { Standardize } \\
\mathrm{d} \\
\text { Coefficients }\end{array}$ & \multirow[b]{2}{*}{$t$} & \multirow[b]{2}{*}{ Sig. } \\
\hline & & B & & Beta & & \\
\hline \multirow[t]{4}{*}{1} & (Constant) & .061 & .391 & & .155 & .877 \\
\hline & SDM & .445 & .062 & .367 & 7.190 & .000 \\
\hline & Manajemen & .341 & .058 & .330 & 5.882 & .000 \\
\hline & Permodalan & .069 & .071 & .046 & .972 & .332 \\
\hline
\end{tabular}




\begin{tabular}{|c|c|c|c|c|c|}
\hline $\begin{array}{l}\text { Inovasi } \\
\text { Produk }\end{array}$ & .079 & .070 & .050 & 1.136 & .257 \\
\hline
\end{tabular}

Persamaan regresi berganda dapat disusun dengan nilai pengaruh SDM, manajemen, permodalan dan inovasi produk terhadap sustainabilitas BMT.

$Y=0,061+0,445 X_{1}+0,341 X_{2}+0,069 X_{3}+0,079 X_{4}+e$

Berdasarkan model persamaan regresi ini, maka dapat diinterpretasi di antaranya:

- Nilai a konstanta $=0,061$. dapat diartikan bilamana $X_{1}$ SDM $X_{2}$ Manajemen $\mathrm{X}_{3}$ Regulasi $\mathrm{X}_{4}$ Inovasi Produk secara konstan, maka $\mathrm{Y}=$ 0,061 satuan

- Nilai b1 =0,445. dapat diartikan bilamana nilai SDM bertambah 1 satuan, sementara nilai $\mathrm{X}_{2}$ Manajemen $\mathrm{X}_{3}$ Regulasi $\mathrm{X}_{4}$ Inovasi Produk bersifat tetap, maka sustainabilitas BMT (Y) akan bertambah sebesar 0,445

- Nilai b2 =0,341. dapat diartikan bilamana nilai _variabel manajemen bertambah 1 satuan, sementara nilai $X_{1}$ SDM $X_{3}$ Regulasi $X_{4}$ Inovasi Produk tetap, maka _variable sustainabilitas BMT (Y) akan bertambah sebesar 0,341 .

- Nilai b3 = 0,069. dapat diartikan bilamana nilai _variable permodalan bertambah 1 satuan, sementara nilai $\mathrm{X}_{1} \mathrm{SDM} \mathrm{X}_{2}$ Manajemen $\mathrm{X}_{4}$ Inovasi Produk tetap, maka _variable sustainabilitas BMT (Y) akan bertambah sebesar 0,069 .

- Nilai b4 =0,079. dapat diartikan bilamana nilai _variabel inovasi produk bertambah 1 satuan, sementara nilai $X_{1} \operatorname{SDM} X_{2}$ Manajemen $X_{3}$ Regulasi tetap, maka _variabel sustainabilitas BMT (Y) akan bertambah sebesar 0,079 . 
mampu eksis, kompetitif hingga sustainabel yaitu faktor SDM, faktor manajemen, faktor permodalan, faktor inovasi produk, faktor regulasi dan faktor makro ekonomi. Melalui analisis faktor untuk mereduksi data, dengan meringkas sejumlah variabel menjadi lebih sedikit maka faktor regulasi dan faktor makro ekonomi menjadi faktor tereduksi.

Hasil temuan penelitian ini bahwa faktor manajemen dan faktor SDM berpengaruh signifikan terhadap sustainabiltas BMT, sedangkan faktor permodalan dan faktor inovasi tidak berpengaruh secara signifikan. Atas dasar teori menunjukkan bahwa faktor manajemen dan SDM. Manajemen menjadi faktor vital dalam BMT karena melalui manajemen dalam menggerakkan SDM, modal dan perangkat lainnya secara terpadu untuk meningkatkan kinerja. Kombinasi antara kebijakan, administrasi dan manajer BMT sebagai pengambil keputusan dan pengawasan yang berjalan secara stabil dalam pertumbuhan usaha BMT.

Sementara faktor yang tereduksi faktor regulasi dan faktor ekonomi makro tidak berdampak terhadap kinerja dan sustaibilitas BMT. Temuan sebagaimana pandangan Chideme bahwa majunya lembaga keuangan mikro tidak memiliki korelasi positif dengan regulasi keuangan mikro dan kinerja makro ekonomi negara untuk sustainabilitas LKM. ${ }^{18}$ Salam juga menemukan bahwa dalam kondisi negara mengalami krisis ekonomi pada tahun 2008 tersebut, tidak berdampak pada melemahnya kinerja koperasi dan BMT, bahkan kemampuan koperasi dan BMT tetap berfungsi dalam pembiayaan di sektor mikro. ${ }^{19}$ Secara umum dapat disimpulkan bahwa faktor yang paling mempengaruhi kinerja LKM adalah manajemen dan faktor SDM.

\footnotetext{
18 "An Assessment of Factors Affecting the Financial Performance of Microfinance Institutions in Zimbabwe," 38.

${ }^{19}$ Salam, Sustainabilitas lembaga keuangan mikro, 18.
} 


\section{DAFTAR PUSTAKA}

Asian Development Bank. "Finance for the Poor: Microfinance Development Strategy." Manila ADB, 2000.

Ayayi, Ayi Cavriel, dan Maty Sene. "What Drives Microfinance Institutions Sustainability," 44:303-24. 1. Journal of Developing Areas, 2010.

Chideme, Nyikadzino. "An Assessment of Factors Affecting the Financial Performance of Microfinance Institutions in Zimbabwe." A dissertation submitted in partial fulfillment of the requirements for the degree of Master of Business Administration 2015, Graduate School of Management University of Zimbabwe, 2015.

Cokrohadisumarto, Widiyanto bin Mislan, Abdul Ghafar Ismail, dan Kartiko A. Wibowo, ed. BMT, Praktik dan Kasus. Cetakan ke-1. Jakarta: RajaGrafindo Persada, 2016.

Galor, Oded. "The Demographic Transition and the Emergence of Sustained Economic Growth." Journal of the European Economic Association 3, no. 23 (1 Mei 2005). https:/ / doi.org/10.1162/jeea.2005.3.2-3.494.

Gomes, Faustino Cardoso. Manejemen Sumber Daya Manusia. Yogyakarta: Andi, 2003.

http:/ / ucs.sulsellib.net/ / index.php?p=show_detail\&id=17721.

Gunawan, Imam. Pengantar Statistika Infrensial. 1 ed. Cet I vol. Jakarta: Raja Grafindo Persada, 2016.

Hartono, Sri Redjeki, Paramita Prananingtyas, dan Fahimah. Kamus hukum ekonomi. Bogor: Ghalia Indonesia, 2010.

Kadir, Abdul. Statistika Terapan: Konsep, contoh dan Analisis Data dengan Program SPSS/Lisrel dalam Penelitian. 3 ed. Jakarta: Raja Grafindo Persada, 2018.

Qayyum, Abdul, dan Munir Ahmad. "Efficiency and Sustainability of Micro Finance Institutions in South Asia." Research Journal Social Sciences 3, no. 1 (2006): 1-34.

Rusydiana, Aam S, dan Abrista Devi. “Aplikasi Metode Analytical Network Process (ANP) untuk Mengurai Problem Pengembangan Baitul Maal Wat-Tamwil di Indonesia," 2013. https://www.academia.edu/download/32794292/Aplikasi_Metode_ ANP_untuk_Mengurai_Problem_Pengembangan_BMT_di_Indonesia.p df.

Salam, Abdul. Sustainabilitas Lembaga Keuangan Mikro: Koperasi Simpan Pinjam. Disunting oleh Hasse J. Yogyakarta: Sekolah Pascasarjana UGM, 2008.

Samsudin, Sadili. Managemen Sumber Daya Manusia. Bandung: Pustaka Setia, 2006. 
Analisis Faktor-faktor Sustainabilits...

Staschen, Stefan. "Regulation and Supervision of Microfinance Institutions: State of Knowledge." Deutsche Gesellschaft für Technische Zusammenarbeit (GTZ) GmbH, 1999.

Tanjung, Hendri, dan Abrista Devi. Metodologi Penelitian Ekonomi Islam. Jakarta: Gramata Publishing, 2013.

Wibisono, Yusuf, dan Tika Arundina. Indonesia shari'ah economic outlook (ISEO), 2011. Disunting oleh Yusuf Wibisono. Jakarta: Lembaga Penerbit, Fakultas Ekonomi, Universitas Indonesia, 2011. 